\title{
Framing Biopolitics/ Biopower
}

\author{
Johannes A. Smit
}

\section{Abstract}

Showing how Michel Foucault moved from his analyses related to disciplinary power, to biopolitics, biopower, governmentality, and political economy, this article seeks to firstly contextualise the study in Foucault's own methodological and discursive oeuvre with regard to his move from 'disciplinary power' to 'biopolitics' and 'biopower'. This is followed by his very brief and concise description of what the study of biopolitics and biopower entail. Secondly, the focus is on Governmentality/ Governmental Reason, with five sub-topics, viz., political economy, regimes of veridiction, the limiting of the exercise of power by public authorities and 'utility', the birth of governmental rationality extended to a world scale (colonisation and imperialism), and the birth of civil society. The study concludes with some remarks related to the distinction between ideal critique, real transformation, and a few perspectives on what real transformation would entail in the postcolony, as it relates to the role of 'thought', the reason in governance, or governmentality.

Keywords: disciplinary power, biopolitics, biopower, governmentality, political economy, regimes of veridiction, the limiting of the exercise of power by public authorities, 'utility', the governmental rationality extended to a world scale, civil society, liberogenic, thought

\section{Introduction}

Opening his lecture series of 1978 - 1979, on The Birth of Biopolitics, on 10 January 1979, Michel Foucault quotes Robert Walpole, the First British Prime Minister (1721 - 1742) on his approach to governing, in 1740: Quieta non movere, 'Let sleeping dogs lie'. This was with reference to, 
counsel of prudence, and we are still in the realm of the wisdom of the prince, that is to say: When the people are peaceful, when they are not agitating and there is no discontent or revolt, stay calm. So, wisdom of the prince (Foucault [1978/ 1979] 2008: 20).

In a footnote, we read Walpole 'governed pragmatically, using Parliamentary corruption, with the aim of preserving political peace' (Foucault/ Senellart [1978/ 1979] 2008: 23, n. 2). This was still in the era of sovereignty in Europe, where populations were supposed to be governed by wise royals and where processes and prospects for colonisation and the development of especially the British slavery systems were still on the up, and growing. And as assumed in this quote, the most important challenge was to keep the peace among the mostly illiterate and uneducated West-European populace.

If we move to the mid-1700s we see Foucault analyse what we may term an incident that symbolically represents the birth of liberalism in Europe. Referencing an anonymous article that appeared in the Journal économique, in 1751, he recounts the story about Jean-Baptiste Colbert (French Minister of Finance under Louis XIV) who asked a French merchant, Le Gendre, 'What can I do for you?', the merchant replied, to say, 'Laissez-nous faire'. At that point, Colbert's economic system - also called 'Colbertism' - was still a mercantilist system ${ }^{1}$. And, in context, what Le Gendre meant, when he said 'let us do', was to say, 'leave us alone'. We do not need, and we do not want government interference in our trade, industry, and business enterprises. So, as

${ }^{1}$ Mercantilism is an economic theory that holds that the trade between states generates wealth, and that trade and wealth are stimulated by the 'accumulation of profitable balances, which a government should encourage by means of protectionism' (Oxford English Dictionary). It does not encourage forms of state interference, controls, regulations, nor taxes, nor investment - such as in infrastructure - for instance. For a current perspective, cf. Patterson's chapter on 'The Triumph of Mercantilist China', in his China, Trade and Power (2018), for a recent assessment of Chinese mercantilist policies in the world system, including reflections on China's State Owned Enterprises, which controls around $50 \%$ of the Chinese economy, of which a large part is unproductive. The question may well be asked as to the nature of the 'tippingpoint' of an economy that switches from a mercantilist to a liberal governmental framework (cf. Optiz 2011:94, 97, 99f). 
a system, laissez faire came to indicate economic transactions between private parties, in which there is no, or minimal government interference. Examples are for instance, regulatory policies, the price controls for the setting of price ceilings and price floors, the instituting of tariffs and subsidies, or, more broadly speaking, any form of government intervention related for instance to slavery and trade related to colonization, or imperialism, just two mechanisms that facilitated the rise of world capitalism.

In these two brief narratives, we see a movement from governance by sovereignty and its related mercantile system to that of the beginning of liberal capitalism - a movement to the economic limitations of governance, and vice versa, the movement to sovereign governance systems' self-limitation in view of the emergence of the liberal capitalist economy. This also constituted the emergence of political economy - the graded distancing of economy from politics, yet still determined by politics, and its forms of governance. This is the historicised discursive frame that Foucault gave to his notion of the emergence in the world system, of what he calls 'biopolitics', or 'biopower'.

My focus in this article is on aspects of the framing that Foucault traced for biopolitics as it developed in the world system, especially in the Western world, and how it would come to impact Europe's colonies, in the forms of 'governmentality' and political economy, determined by the emergence of 'liberalism'. Firstly, I contextualise the study in Foucault's own methodological and discursive oeuvre with regard to his move from 'disciplinary power' to 'biopolitics' and 'biopower'. This is followed by his very brief and concise description of what the study of biopolitics and biopower entail. Secondly, I focus on governmentality/ the analytics or reason of governmen, with five sub-topics, viz., political economy, regimes of veridiction, the limiting of the exercise of power by public authorities and 'utility', the birth of governmental rationality extended to a world scale, and the birth of civil society.

Granted that Foucault's own approach to these thematised analyses, were from the late 1970 s, I deploy these aspects as a mosaic of themes, to provide a partial frame for the generation of some multifocal insights into Foucault's researches on 'liberalism'. Foucault's analyses formed part of discourses on the factualities and origins of neo-liberalism and how twentieth century rationales of government, framed economics, in forms of neoliberalism. My own analysis, may provide a few critical and transformatively relevant perspectives on the current challenges faced by the Southern Africa, 
and African economies, for the future developments of rationales, or reasons(s) of governing the interactive and continental rise of African economies - their economentalities - in the wake of the African Union's launching of the operational phase of the Africa Continental Free Trade Area (AfCFTA). This will be the 'world's largest free trade area by number of countries once it's fully up and running'.

\section{Context}

\section{From Disciplinary Power to Biopolitics/ Biopower}

Publicly, Foucault coined the notion of 'disciplinary power' in his lecture series of 1973 - 1974, on 21 November 1973, and invigorated the notions of 'biopolitics' and 'biopower' with radically new connotations, on 17 March $1975^{2}$.

I would like to advance the hypothesis that something like disciplinary power exists in our society. By this I mean no more than a particular, as it were, terminal, capillary form of power; a final relay, a particular modality by which political power, power in general, finally reaches the level of bodies and gets a hold on them, taking actions, behavior, habits, and words into account (e.a. Foucault [1973/ 1974] 2006: 40).

To note is that Foucault's metaphor 'capillary form of power', references the fine branching blood vessels or the network of blood vessels as fine as hair in the human body. In the same way that a person's blood runs through the fine blood vessels of the body, so, he assumes, in his development of the genealogical methodology, discipline is being instilled from outside onto and into the behaviour or conduct of the 'body' of the citizenry, and by implication, also somatically, on each and every human body, as to how it conducts itself. In the modern world, it constitutes the very life of being human. It is well known how he then developed this empirical, historical analytics of the notion

${ }^{2}$ For a brief overview of how the notion of biopolitics have informed different, and also opposing discourses and discursive formations in the past, cf. Lemke (2011:165f). As is evident from Foucault's lecture series, The Birth of Biopolitics ([1978/ 1979] 2008), his focus was primarily on how forms of neoliberalism framed biopolitics and biopower in the post-WWII period. 
of disciplinary power over a period of two years, in conjunction with his nominalist genealogical methodology, culminating in his book Discipline and Punish (1976).

Then, moving to biopolitics and biopower two years later, in his own words, and referencing his metaphor of 'capillary' disciplinary power, or the 'anatomo-politics' of the human body, and by implication the 'body' of the citizenry, and his movement to biopolitics and biopower, Foucault ([1975/ 1976] 2003: 243) says,

After the anatomo-politics of the human body established in the course of the eighteenth century, we have, at the end of that century, the emergence of something that is no longer an anatomo-politics of the human body, but what I would call a 'biopolitics' of the human race. What does this new technology of power, this biopolitics, this biopower that is beginning to establish itself, involve?

Answering his question, amongst others, a little later in his lecture, he says,

[Biopolitics is] ... control over relations between the human race, or human beings insofar as they are a species, insofar as they are living beings, and their environment, the milieu in which they live. This includes the direct effects of the geographical, climatic, or hydrographic environment [think Herder for instance]: the problem, for instance, of swamps, and of epidemics linked to the existence of swamps throughout the first half of the nineteenth century. And also the problem of the environment to the extent that it is not a natural environment, that it has been created by the population and therefore has effects on that population. This is, essentially, the urban problem. I am simply pointing out some of biopolitics' starting points, some of its practices, and the first of its domains of intervention, knowledge, and power: biopolitics will derive its knowledge from, and define its power's field of intervention in terms of, the birth rate, the mortality rate, various biological disabilities, and the effects of the environment (Foucault [1975/ 1976] 2003:245).

And, in their 'Situating the Lectures' of 1975 - 1976, of this year's lectures, Alessandro Fontana and Mauro Bertani (2006:274) explain, 
Foucault's course of lectures on Society Must Be Defended ${ }^{3}$ opens with a sort of survey or summary of the general features of 'disciplinary' power - a power that is applied to individual bodies by techniques of surveillance, normalizing sanctions, and the panoptic organization of punitive institutions - and ends with an outline presentation of what he calls 'biopower' - a power that is applied in general ways to the population, life, and living beings. In an attempt to establish a 'genealogy' for this power, Foucault subsequently investigated 'governmentality', or the power that has, since the late sixteenth century, been exercised through the apparatuses and technologies of reason of State and policing.

To note, is Fontana and Bertani's capture of this movement in Foucault's thought from his theorizing and related empirical archival studies of 'disciplinary power' to 'biopower' in 1975/ 1976, and then his subsequent investigations of what he termed 'governmentality', framing both. These are just two perspectives that lead up to his lectures of 1978/ 1979.

So, in the Western world system, also impacting the colonies throughout the colonising processes, systems of governmentality have framed both the development of disciplinary power and biopolitics, or biopower, as well as the political economy that arose in the mid-1700s.

\section{Framing Biopolitics/ Biopower}

Another three years later, when Foucault reflects back on the year's course of 1978 - 1979, retroactively, he says in his 'Course Summary' of 1979 ([1978/ 1979] 2008: 317ff), that what he had in mind when he coined the re-invigorated the notion of biopolitics with new historicisings within the framework of his study of neoliberalism, was to study the attempts by European governments,

... to rationalize the problems posed to governmental practice by phenomena characteristic of a set of living beings forming a population: health, hygiene, birth rate, life expectancy, race .... We know the increasing importance of these problems since the nineteenth

3 This refers to Foucault's annual series of lectures from 1975/1976 - three years prior to The Birth of Biopolitics ([1978/ 1979] 2008) annual series. 
century, and the political and economic issues they have raised up to the present (Foucault [1978/ 1979] 2008: 317).

These are the kinds of concerns about which modern governments have to generate data, interpret them, and then according to which, they have to govern, viz., 'health, hygiene, birth rate, life expectancy, race'. These are the kinds of issues that concern population ${ }^{4}$, and what Foucault calls from governance perspective, biopolitics, and biopower.

Foucault then concedes, that this, in the end was not what he had actually ended up doing his research on during the past year, or, at least what he decided to deliver in the lectures of 1978 - 1979 from his corpus of research conducted - the different focuses of biopolitics or biopower. Rather, he ended up focusing on a problematisation of 'governmental practice', how governmental practices have evolved since the $16^{\text {th }}$ century. He then termed the study of these governmental practices the study of 'governmentality', or the reason or rationalities of government as they have developed in the world system. And, in his view - and this was around a century before the emergence of Karl Marx - he found the 'birth' of these governmental practices, in the mid-1700s', in 'liberalism'.

If we take into consideration then, that Foucault has in fact not lectured on the factualities of biopolitics and biopower in his lecture series of 1978 1979, his metaphor of the 'birth' synchronises with the notion of his sense of his latent framing of biopolitics and biopower, as it developed in the West since the midst 1700s. His vantage point though - and which occupies seven of his twelve lectures on 1978/1979, is that of the nature of neo-liberalism in the post-WWII era, as it came to manifest in especially German and the USA. His notions of governmentality, and liberalism, or more specifically, liberal governmentality or the reason or rationales of liberal governance of the twentieth century, and how they are rooted in the emergence of liberalism since

${ }^{4}$ From the listing of these topics, it is evident, that all of them - 'health, hygiene, birth rate, life expectancy, race, etc.' - are aspects of population studies. From Foucault's published research - and we may assume that there is much more of this in his unpublished research. With all the digital and related tools for studying these topics that have arisen over the last three decades, it might even be labelled the science(s) of population or, in terms of the focuses and nuances we find in the discipline, Population Studies. 
the $16^{\text {th }}$ century, but especially since the mid-1700s as referenced above, with regard to the French merchant Le Gendre, provide the frame for the study of biopolitics, and biopower. For his own development of the 'how' of governmentality, or an 'analytics of government', Foucault's own seminal contribution was, in Lemke's words, at the time, to not participate in discourses of the 'reinvention of government' according to forms of privatization, nor in the "economic horror" of aspects of globalization'. Rather, and I herewith concur with Lemke (2012:39), it was to, provide the tools to analyse the 'relational, technological, and strategic' approaches of governments, as his contribution to the 1970s scholarly work in Europe on 'neo-liberalism' inherent in the liberal world governmentalities of the mid-twentieth century.

So, the problematisation of governmentality since the mid-1700s, is in fact a problematisation of liberalism, and for political economy, the problematic complex of relations between governance, the indicative of governance's biopolitics and biopower in terms of which it seeks to manage and administer the modern state, and liberal capitalist economy. This then is the frame, the birth of biopolitics and biopower - the governance of life - the bios - and the complex relations of governance with liberalism, and more specifically the liberal capitalist economy.

To note too, is that of all his 14 years of lectures and books he published during his time at the Collège de France, is that all Foucault's studies were historical, focusing on pre-twentieth century developments, except for this year's lectures, $1978-1979$, that was published as The Birth of Biopolitics. Except for his focus on grounding his research in the $16^{\text {th }}$ and $17^{\text {th }}$ centuries, in the first three lectures, and reflecting on the historical groundings of civil society in the last two, the main corpus of lectures focuses on twentieth century political economy - five lectures on what he then termed the 'neoliberalism' of post-Nazi Germany (1945 - 1962), and two lectures on what he termed American 'anarcho-neoliberalism' in the post-World War II era.

In this article I do not focus on these seven lectures' two aspects of 1978 - 1979. Rather, as said, the focus is only on five selected aspects of this focus on governmentality, as they frame biopolitics and biopower, and by implication, its complex relations with foundational aspects of the liberal market capitalist system, or, in its origins, political economy since the mid$1700 \mathrm{~s}$. Seeing these five aspects together, one may regard them as a multi-focal mosaic of themes that on the one hand interpreted the forms of neoliberalism that emerged in Germany and the USA in the post-WWII era. On the other 
hand, they are useful, in our own African context, in so far as they provide specific conceptual perspectives that may generate data for the development of a coordinated analytics of governmentalities of the modern African nationstates in the time of the emergence of the AfCFTA pact, for its prospective future forms of development.

\section{Governmentality/ Governmental Reason Political Economy}

Political economy, emerged as the 'principle of the internal limitation' of government, and developed too, as a 'science', 'lateral to government', and a 'critique of government'. It is an ambiguous concept, in so far as it oscillates between the semantic pole of politics or governance and the economy. During the period, $1750-1810-1820$, it basically had three reference points, viz.

Sometimes this expression aims at a particular strict and limited analysis of the production and circulation of wealth. But, in a broader and more practical sense, 'political economy' also refers to any method of government that can procure the nation's prosperity. And finally, political economy - the term employed by Rousseau in his famous article in the Encyclopedia - is a sort of general reflection on the organization, distribution, and limitation of powers in a society .... fundamentally it was political economy that made it possible to ensure the self-limitation of governmental reason (Foucault [1978/ 1979] 2008:13).

It is this latter focus that has become the dominant in the modern capitalist world economy, at least where it has not become 'anarchic'. It may also be articulated with regards to the three epochs of sovereignty, the period of the reason of state and the period of the modern world economy. During the time of sovereignty, the question was: 'Am I governing in proper conformity to moral, natural, or divine laws?'. Then in the sixteenth and seventeenth centuries, the time of the 'reason of state', or, raison d'État, the question became, 'Am I governing with sufficient intensity, depth, and attention to detail so as to bring the state to the point fixed by what it should be, to bring it to its maximum strength [during the mercantalist period, and in competition with, fellow, European states]?' Since the dawn of 'liberalism' in the middle 
of the 1700s, the question became, 'Am I governing at the border between the too much and too little, between the maximum and minimum fixed for me by the nature of things' (Foucault [1978/ 1979] 2008: 18f).

The great ambiguity in the interface between governance and the economy is then precisely political economy, which is a space with no clear and universal markers, or laws, for that matter. Even so, governmentality, or the reason of government is the frame of the workings of biopolitics and biopower in interaction with and vis-à-vis the liberal world economy.

This then raises the 'specific features of the liberal art of government' or the basic form of government that has as its objective forms of biopolitics or biopower, as the governance of life or of populations, as they function and operate as economic actors and entrepreneurs.

\section{Regimes of Veridiction}

Since the emergence of liberalism, as it was not only formed by the selflimitations by governance, but by the market economy in turn, modern governmental practices have been limited by a constitution, and parliament; opinion and the press; and commissions and inquiries. It has developed for itself, internal limits which are continuously assessed by governance systems, that Foucault accordingly calls systems of 'veridiction'. Veridiction, or the decisions of the truth of governance in specific contexts, functions in the space of the ambiguity between politics or governance and the economy - the '[h]eterogeneity [characterised by] tensions, frictions, mutual incompatibilities, successful or failed adjustments, unstable mixtures'. In the world systems, governance is confronted with two extremes, viz. between '[r]evolutionary procedure [that] adopts the method of exhaustive governmental conditions'; and the radical break-up of even the internal governance self-limiting systems, leading to 'international objectives and the appearance of unlimited objectives with imperialism'. As such,

Liberal reason is correlative with activation of the imperial principle, not in the form of the Empire, but in the form of imperialism, and this in connection with the principle of the free competition between individuals and enterprises (Foucault [1978/ 1979] 2008: 21, n. 4).

Turning on the notion of the degree of the self-limitation of government, or the 
degree of 'frugal government' since the $16^{\text {th }}$ and $17^{\text {th }}$ century, responses may also vary between resistance and revolts and invasions of government in economic practices (cf. Foucault [1978/ 1979] 2008: 28).

Within Western governmentality, the principle of veridiction then emerges in the market, e.g. with jurisdictions related to 'distributive justice', as they concern the 'truth of prices', 'absence of fraud', 'absence of theft and crime', 'the quality of goods', but also the 'relative consistency of currencies', 'a continuous economic and demographic growth' and 'an intensification of agricultural production' amongst others (cf. Foucault [1978/ 1979] 2008: 30 $33)$.

\section{The Limiting of the Exercise of Power by Public Authorities and 'Utility'}

Within the domain of the limiting of governmental power the one that is significant in the African context is the one that starts from 'governmental practice itself'. It concerns the 'de facto limits that can be set to this governmentality'. In the reason(s) of how governance is deployed, these limits that governance systems set for themselves,

... may derive from history, from tradition, or from an historically determined state of affairs, [as well as] ... desirable limits ... as the good limits to be established precisely in terms of the objectives of governmentality, of the objects with which it has to deal, of the country's resources, population, and economy, etc. (Foucault [1978/ 1979] 2008:40).

For governmental practice, the limits or self-limitation by government may derive from 'history, tradition, or from an historically determined state of affairs'. There are many aspects to these, especially as to their complexities, that we shall not elaborate on here. Suffice to say that in the analytics of governmental practices, analyses should focus on issues, objects or matters such as the 'de facto limits, and its desirable limits', i.e. those things that government would be ill advised or 'absurd', or 'pointless' for government to 'tamper' or 'interfere' with. The point at issue though remain as to ask the question on the precise points at which government is interfering, should 
interfere, and where it is desirable, for the good of the resources, population and economy, etc. not to interfere. And closely related, if something works for the production and development of resources, if something works for the population, if something works for the economy, to not 'tamper' or 'interfere' with it. (This is akin to Walpole's notion of 'let sleeping dogs lie'.)

Closely associated with reflexive evaluations of governance systems' limits, and self-limitations, of their 'spheres of competence', in its exercise of power, concern questions of the usefulness of governance systems' technologies or practices or interventions, as these derive from certain rationalities.

The question addressed to government at every moment of its action and with regard to each of its institutions, old or new, is: Is it useful? For what is it useful? Within what limits is it useful? When does it stop being useful? When does it become harmful? This is not the revolutionary question: What are my original rights and how can I assert them against any sovereign? But it is the radical question, the question of English radicalism; the problem of English radicalism is the problem of utility (Foucault [1978/ 1979] 2008:40).

The radical limitations of government, and also self-limitations of government are therefore aimed at opening the space of the participation of the citizenry in full interaction with governance in the development of the country. Practically, this is not a question of ideology, or even more generically, the political system, in terms of which governance is reflexively steered and managed. It is rather a question of precisely the nature of reason, the rationality, and what this rationality's intended and hoped for outcomes are with regard to the usefulness of its technologies. How, have these technologies been thought through, according to which (juridical) rules and regulations, and for what measurable outcomes and ends. So, the question does not concern ideology. Independent of ideology, the question concerns the usefulness of certain techniques of governance ... the governmentality ingrained in the techniques, or practices (Foucault [1978/ 1979] 2008: 40f). These are important questions in the African context. They may help to develop the reasoned maximisations of the space(s) and instruments for the full participation of the African citizenries in the continent's economies, in whichever ideological or philosophical formation they may present themselves, and into which they morph and transform. 


\section{The Birth of Governmental Rationality Extended to a World Scale}

During the period of the rampant colonisation of the world by European powers, commerce was the prime instrument of the enrichment of the European countries, and by default, the instrument through which the European states could increase their power vis-à-vis competing states with regard to resources and wealth. Here too, the self-limitation of governments played a role, to various degrees. And, in order to retain governmental control, these countries followed primarily three strategies, viz.

(1) the management of dangers and the implementation of mechanisms of security; (2) disciplinary controls (Bentham's panopticism); (3) interventionist policies. The management of liberty and its crises.

In order to obtain and retain an economically hegemonic and politically imperialist advantage, they had to implement these strategies among their own populations, as well as those that they subjugated in processes of colonisation. Dangers had to be managed and a wide variety of security measures developed - security with regard to wealth and goods, (settler) populations, as well as trade and commerce. Disciplinary controls had to be developed, and permeated society into its finest 'capillary' networks, as 'disciplinary power' was instilled in populations, both at home, and those subjugated in the colonies. Bentham's well-known panopticon, dating from the 1830s, has become an emblem of such discipline, as it is also linked and articulated with surveillance. And, finally interventionist policies that had to ensure not only the security and protection of wealth and material goods, but also their continued accumulation and expansion.

\section{The Birth of Civil Society}

With the democratic world, 'civil society' has emerged as a concept that captures the integrated economic life of citizens, as this multiplicity exist as not being part of governance systems, and also not in primary economic systems. In some versions, civil society is different from both governance, including active politics, and the economy, the entrepreneur or Homo oeconomicus. Related to governance, it has to be articulated with both juridical 
systems and the economic, and will overlap to various degrees in some cases. It concerns,

... how to govern, according to the rules of right, a space of sovereignty which for good or ill is inhabited by economic subjects. How can a reason, a rational principle be found for limiting, other than by right or by the domination of economic science, a governmental practice which must take responsibility for the heterogeneity of the economic and the juridical? ... Civil society is, ... a concept of governmental technology, or rather, it is the correlate of a technology of government the rational measure of which must be juridically pegged to an economy understood as process of production and exchange. The problem of civil society is the juridical structure (économie juridique) of a governmentality pegged to the economic structure (économie économique) (Foucault [1978/ 1979] 2008:295f.

The notion of 'civil society', which is sometimes just referred to as 'society', or even the 'nation', in distinction and often vis-à-vis the government, or even the state, has developed in a wide variety of forms in the world system since Locke and then Ferguson theorised it. For its own actual functioning, its management is coordinated in governmental technologies and practices, according to governance systems' internal imperatives, which may differ from country to country, or even nation to nation, if not state to state and province to province in the developing world. These will be according to the population and climatic variables for instance. And rather than seeing it in juridical terms, the challenge is precisely to foster it in such ways as to maximise the opportunities for the general economic practices of the populace. The challenge is to critically reflect on the actual technologies of government. This becomes crucial for enhancing and maximising forms of sustainable self-sufficiencies via processes and protocols of government self-limitation and the fostering of $\operatorname{art}(\mathrm{s})$ of government, in specific contexts, and according to their specificities.

Since the limits between governance and economy are always fluid, within the limits posed by juridical frameworks, the same is true for those between the spheres of the economy and society or nation. In some radical perspectives, in radical understandings of the economic systems of a country, one may even pose a nearly complete overlapping of economy and society visà-vis the reflexive self-limitations or frugalities by and of government. 
Homo oeconomicus and civil society are therefore two inseparable elements. Homo oeconomicus is, if you like, the abstract, ideal, purely economic point that inhabits the dense, full, and complex reality of civil society. Or alternatively, civil society is the concrete ensemble within which these ideal points, economic men (sic.), must be placed so that they can be appropriately managed. So, homo oeconomicus and civil society belong to the same ensemble of the technology of liberal governmentality (Foucault [1978/ 1979] 2008:296).

Where, in state formation discourse, we usually distinguish between the overlapping and mutually impacting and integrated sectors of politics $\rightarrow$ economy $\rightarrow$ and civil society, in the frame of the state, it is important to consider this form of the closer integration, if not 'fully' overlapping, of economy and civil society. This is certainly food for thought - the consideration of specific limits and opportunities, on the gliding scale in the spectrum of 'the' economy and 'the' civil society, from the perspective of society, the nation, and from the ground up so to speak.

\section{The Libèrogénes/ Liberogenic and Critique}

For the development and fostering of optimum forms of reflexivity of governance systems, and the reflexive sensitivities to the nation, even wellmeaning governance systems may have counter-outcomes contrary to laudable intentions. Of radical liberal governmentality, for instance, Foucault ([1978/ 1979] 2008:68f) says,

... there are processes of clogging, such that the mechanisms for producing freedom, precisely those that are called upon to manufacture this freedom, actually produce destructive effects which prevail over the very freedom they are supposed to produce. This is, if you like, the ambiguity of all the devices which could be called liberogenic (libèrogénes), that is, devices intended to produce freedom which potentially risk producing exactly the opposite.

This is precisely the present crisis of liberalism. It has developed in the world system, primarily lateral and often in a strained relationship with Western powers. It has also been the system that most detrimentally impacted the 
West's colonies of the world, which were severely exploited despite some philanthropic and religious and civil society antagonism and advocacy against colonisation, as we for instance find in the anti-slavery lobby, and first the abolition of the salve trade, and ultimately the abolition of slavery itself (cf. Smit 2016). Yet, it has also been the system through which the world has been able to create the space for the generation of the most advanced scientific and modernization projects.

Contrary to these views though, as Foucault references, contrary to intended consequences, even such ideologies that proclaim(ed) freedom may not always in their effects, produce freedom for all, and that not equally. Especially where one has been on the receiving end of colonisation, the system has had, and continues to have counter-effects. This was the main reason for the seeking of freedom, liberation and independence by the peoples of former colonies. And this raises the question of critique, the critique of thought, the critique of the reason(s) of governance, the critique of a reigning governmentality, and the reasons of governing a specific ways - governing 'like that'. Whereas ideal critique, references the idealism that always inform utopian political or governance or social forms. Real, engaged critique involves questions of transformation, and the complex questions of the transformational steps to be taken towards certain specific outcomes and ends.

[C]riticism (and radical criticism) is absolutely indispensable for any transformation. A transformation that remains within the same mode of thought, a transformation that is only a way of adjusting the same thought more closely to the reality of things can merely be a superficial transformation.

On the other hand, as soon as one can no longer think things as one formerly thought them, transformation becomes both very urgent, very difficult, and quite possible (e,a, Foucault 1981:155).

If it becomes impossible to think things as formerly thought - and taught - the realities of the challenges of transformation, i.e. real transformation, especially as a specific reason of government, governmentality, frames a nation's biopolitics and biopower, the main challenge is to develop this towards the maximising of the nation's wellbeing and prosperity. This, in the postcolonies of Africa, and not least with the promises of the AfCFTA on the horizon, become 'urgent, very difficult and quite possible'. 


\section{Conclusion}

The birth of governance, and its complex relations with forms of liberalism and especially the liberal capitalist world economy, as a system, came about due to the emergence of modern world democratic systems. Economically, this meant too, the birth of consciousness about the degree of government interference in the economy, in trade, in industry, and in business, and vice versa. Alternatively said, it means the introduction of notions, and strategies (and judicial systems) of self-limitation by governance systems, as to the freedom the economy has with regard to economic activities, including the rise of the notion of civil society, comprising of economically active men and women. It also saw the dawn of governmental systems - reasons of state - aimed at the limiting, or regulation of the state in economics, and, if we continue to talk about the art of government, the sensitivities government has to deploy to encourage economic activity for purposes of real transformation.

This article has attempted to pinpoint some of the aspects, or variables that are important to reflect on for the advancement and critically-engaged transformation, of a frame for the study of biopolitics and biopower, from perspectives derived from the ideals of freedom and liberation. On a spectrum, these could be said to range from forms of self-limitation by governance, through regular and strategic interventions with regard to aspects related to the thematics of biopolitics and biopower, to the encouragement of economic activity and action amongst the citizenry, functioning as part and parcel of civil society, or the nation. In some strategic cases, where things work, it might be best to follow Walpole's advice, i.e. to let sleeping dogs lie, and, if it cannot be rooted out, to manage corruption so that it does not bring down the whole edifice of the nation. But the reasoning associated with governmentality, the analytics of government, and this in the wake of the launching of AfCFTA, raises questions concerning what we may term the developing of arts of government, and governance, lateral to the art(s) of economics. How could the African nations, develop strategies, social relations, and reflexivities, to optimally and reasonably govern populations in postcolonies, seeking social and personal advancements in health, wellbeing, prosperity and wealth on the African continent. How could the opportunities for populations be maximised? And, here, I want to quote Foucault (2008:22) - a quote that Lemke (2011:165) also uses, but for his own purposes:

... only when we know what this governmental regime called libera- 
lism was, will we be able to grasp what biopolitics is.

It was under regimes of practices of liberalism, its regimes of truth, that the most fierce and vicious colonisations or colonisation mentalities ruled the world for a very long time. It was also during these fierce forms of regimes of liberalism in Europe that the postcolonial imperial built their mercantile and extractionary economentalities, and strategically deployed and implemented them, via liberal economies, as these pertain to the raw resources from the colonies and the de-humanising labour of slaves and serfs. So, the analytics of liberalism, to analyse and come to know this liberalism, and also its subsequent forms of neoliberalism, is of paramount importance in the postcolony, since, according to all available evidence, it is precisely this liberalism, and its neoliberalist economentalities that are - if we extend Foucault's hints about impacts on the environment and vice versa - destroying the planet at exponential rates.

The role 'thought' as a collective and integrated practice plays in all these endeavours, to critically analyse and also construct and mobilise rival economentalities for the future of the planet may be vital, also with regard to the kind(s) of biopolitics and biopower to be developed and to be deployed, within the broader framework(s) of freedom. So, the role of reason of government, or governmentality, as it not only provides the size and shape, and steers biopolitics and biopower, but also provides a productive space for the citizenry in civil society, i.e. for economically productive women and men, is of paramount importance. In this endeavour, thought from the 1700s, or as Wallerstein already averred, from the 1800s (cf. Smit 1999), may not be helpful, especially in the digital world of the present and the future (cf. Smit \& Chetty, 2018a; 32018b; 2018c).

And, in order to facilitate the maximisation of economy on the African continent, in the African postcolonies, in the wake of the African Union's launching of AfCFTA, the analytics of both past and future economentalities appears to be vital, not least from incisive Humanities perspectives. This includes the problematisations of the still continuing and reigning governmentalities of Western Europe - even as their own populations are subjugated and 'protected' from the realities of this disastrous discursive history of the present, in the world system. But, ultimately, it seems that we have reached a tipping point in the eonomentalities of Africa, i.e. from that of Africa's still yet young territorial nation-states, subjugated to forms of 
economic erosion from the outside via leverages of corrupt governance systems, to that of 'a single market for goods and services across 54 countries' (cf. Cloete 2019; Lemke 2012). As argued in this article, the questions about how this emerging market will be framed governmentally, or economentally, cannot, and should not be thought apart from its effects on the nature of biopolitics and biopower, as these will be transformatively impacted by this vast new economic market, and vice versa. And the five-themed, multi-focal interpretive aspects of the conundrums related to the emergence of liberalism in the world system, as explicated by Foucault, may be helpful.

\section{References}

Cloete, K. 2019. Africa's New Free Trade Area is Promising, yet Full of Hurdles. World Economic Forum on Africa. 06 September 2019. Available at: https://www.weforum.org/agenda/2019/09/africa-just-launched-theworld-s-largest-free-trade-area/

Dean, M. 2014. Governmentality: Power and Rule in Modern Society. $2^{\text {nd }}$ Edition. Los Angeles, London, New Delhi: Sage.

Fontana, A. \& M. Bertani 2006. Situating the Lectures. In Society must be Defended. Lectures at the Collège de France 1975 - 1976. Bertani, M. \& A. Fontana (eds.). Macey, D. (trans.). New York. Picador. Available at: foucault_society_must_be_defended_1_\%20(1).pdf

Foucault, M. [1973/ 1974] 2006. Psychiatric Power. Lectures at the Collège de France. Lagrange, J. (ed.). Burchell, G. (trans.). New York: Palgrave/ Macmillan.

Foucault, M. [1975/ 1976] 2003. Society must be Defended. Lectures at the Collège de France 1975 - 1976. Bertani, M. \& A. Fontana (eds.). Macey, D. (trans.). New York. Picador. Available at: foucault society must be defended $1 \% 20(1)$.pdf

Foucault, M. 1977. Discipline and Punish. Sheridan, A. (trans.). New York: Pantheon.

Foucault, M. [1977/ 1978] 2008. Security, Territory, Population. Lectures at the Collège de France 1977 - 1978. Senellart, M. (ed.). Burchell, G. (trans.). New York. Picador. Available at: http://www.azioni.nl/platform/wp-content/uploads/2013/04/FoucaultSecurity-Territory-Population.pdf 
Foucault, M. [1978/ 1979] 2008. The Birth of Biopolitics. Lectures at the Collège de France 1978 - 1979. Senellart, M. (ed.). Burchell, G (trans.). New York. Picador. Palgrave Macmillan. Available at:

https://b-ok.org/book/813859/856ce5 and,

https://www.goodreads.com/book/show/16897578-the-birth-of-

biopolitics

Foucault, M. [1981] 1988. Practicing Criticism. In Kritzman, L. (ed.): Politics, Philosophy, Culture: Interviews and Other Writings, 1977 - 1984.

Sheridan, A. et al. (trans.). London: Routledge.

Lemke, T. 2000. Foucault, Governmentality and Critique. Paper presented at the Rethinking Marxism Conference, University of Amherst (MA), September $21-24,2000$. Available at:

http://www.thomaslemkeweb.de/publikationen/Foucault,\%20Governme ntality, \%20and\%20Critique\%20IV-2.pdf

Lemke, T. 2011. Beyond Foucault: From Biopolitics to the Government of Life. In Bröcking, U., S. Krasmann \& T. Lemke (eds.): Governmentality:

Current Issues. New York \& London: Routledge, and Taylor and Francis. Lemke, T. 2012. Chapter 2: A Genealogy of the Modern State. In Foucault, Governmentality, and Critique. New York \& London: Routledge.

Opitz, S. 2011. Government Unlimited: The Security Dispositif of Illiberal Governmentality. In Bröcking, U., S. Krasmann \& T. Lemke (eds.): Governmentality: Current Issues. New York \& London: Routledge, and Taylor and Francis.

Smit, J.A. 1999. 'Unlthinking White Mythologies', Alternation 6,1 (1999) 237-254. Available at:

http://alternation.ukzn.ac.za/Files/docs/06.1/16\%20Smi.pdf

Smit, J.A. 2016. J.T. van der Kemp's Link to the British Anti-slavery Network and his Civil Rights Activism on Behalf of the Khoi (1801 - 1803). Journal for the Study of Religion 29,2: 5 - 28. Article available at: http://www.scielo.org.za/pdf/jsr/v29n2/02.pdf

Smit, J.A. \& D. Chetty 2018a. 23/ 25 Years of Alternation, and the African Digital Humanities: Capacity, Communication, and Knowledge-Power. Alternation 25,1: 8 - 30.

https://doi.org/10.29086/2519-5476/2018/v25n1a2

Smit, J.A. \& D. Chetty 2018b. Designing Equitable Foundations for Open Knowledge: Access, Freedom \& e/Quality. Alternation Special Edition 23: $8-33$. 
https://doi.org/10.29086/2519-5476/2018/v25n1a15

Smit, J.A. \& D. Chetty 2018c. Designing Heterotopic Transversal Equitable Foundations for Open Knowledge: Access, Freedom \& e/Quality. Alternation 25,1: 8 - 33. Available at:https://doi.org/10.29086/25195476/2018/sp23a2

Paterson, S. 2018. China, Trade and Power: Why the West's Economic Engagement has Failed. London: London Publishing Partnership.

Johannes A. Smit Editor-in-Chief Alternation University of KwaZulu-Natal smitj@ukzn.ac.za 